\title{
The development of shared values: impact on employee behaviour and on customer perception of service
}

\author{
Adèle Thomas* \& Robyn Doak \\ Graduate School of Business Administration, University of the Witwatersrand, P. O. Box 98. Wits. 2050) South Africa \\ thomasa(a)zeus.mgmt.wits.ac.za \\ adelet@megaweb.co.za
}

Received February 2000

\begin{abstract}
Diversity of employees in the workforce is increasingly becoming a feature of South African business. Current debate in South Africa has concerned the marginalisation of groups of employees who, historically, have never been part of establishing existing corporate cultures, and accordingly, it has been argued that tensions exist in the workplace with a related negative impact upon company performance. The main aim of this exploratory study was to investigate whether the negotiated values system operating at a South African marketing and communications company impacts on decision making. cultural interaction and behaviour towards fellow employees and customers. A second aim of the study was to investigate whether the list of negotiated values at the company could be clustered into values categories for possible consideration by other organisations. The findings of the study appear to indicate that the negotiated values system positively impacts upon decision making in the company and upon employee behaviour both towards fellow employees and towards customers. The system also facilitates interaction and understanding amongst culturally diverse employees. It is also possible to cluster the values into four values categories that govern behaviour in different areas namely behavioural. interpersonal. developmental and team building values. It is concluded that the negotiated values system might be indicated as an effective tool for managing employee diversity in South African companies, both for the internal working together of employees and for the promotion of effective customer service.
\end{abstract}

*Author to whom correspondence should be addressed.

\section{Introduction}

South African business is confronted with the challenge of global competitiveness. The World Competitivness Yearbook (IMD, 1999) indicates that South Africa lags in $42^{\text {nd }}$ place among the 47 industrialised countries under review. Despite the application of international management principles, many companies are still suffering from problems of low productivity and profitability, as well as low levels of trust and motivation within their workforces (Thomas, 1996; Thomas \& Robertshaw, 1999). Current labour legislation in the country, and specifically the recently introduced Employment Equity Act (Republic of South Africa, 1998) will require greater democracy in the workplace and higher levels of participation between management and the general workforce. At the same time, employment equity initiatives, as required by the Employment Equity Act (Republic of South Africa, 1998), will increasingly introduce, particularly at senior levels, employees into the workforce, who have, in many cases, thus far been excluded from such positions. It can be expected that the South African workplace will evidence greater diversity than ever before in the forthcoming years. While initiatives directed at achieving employment equity may result in diversity in the workforce, the greater challenge exists to lead and manage this diversity for competitive advantage.

\section{Literature review \\ Diversity in the workplace}

Internationally, Thomas (1991), Morrison (1992), Cox (1993) and Lattimer (1994) have documented the benefits to business of employee diversity that may include: tapping into skills not previously available in a company characterised by an homogeneous workforce; enhancing company creativity and problem-solving; responding quickly and effectively to diverse markets and managing productive relationships with diverse customers, suppliers and distributors; promoting a culture of inclusivity. critical to a commitment to total quality; enhancing team performance; and attracting and retaining the best talent especially amongst those representing new consumer markets. Thomas \& Ely (1996) also note that diversity encourages different and creative insights and styles in approaching the design of business processes and tasks. in the achievement of goals, in the creation of effective teams and in the communication of ideas, amongst others. Cox. Lobel \& McLeod (1991) note the tendency towards more cooperative choices amongst ethnically diverse groups than amongst all-Anglo groups and McLeod \& Lobel (1992) report that ethnically heterogeneous groups produce higher quality ideas in brainstorming activities than do homogeneous groups, a finding supported by Watson. Kumar \& Michaelson (1993). Positive results relating top management team diversity to corporate performance and strategic decision making have also been reported by Bantel \& Jackson (1989), Wiersema \& Bantel (1992) and Glick. Miller \& Huber (1993).

International research. however. indicates that when employees, not formerly part of established organisational cultures, are introduced into such environments, problems may occur. Tsui, Egan \& O'Reilly (1992) found that individuals who are racially and ethnically different from others in their work units tend to be less psychologically committed to their organisations, less inclined to stay with the organisation and more likely to be absent. Greenhaus. Parasuraman \& 
Wormley (1990) note that blacks in the United States tend to be less satisfied with their careers than whites, and also perceive themselves to be less accepted by their organisations and to have less discretion than whites in the same organisations. These themes appear to underlie a common perception of possible exclusion within historically established corporate cultures of organisations.

\section{Culture and values}

According to some South African writers, the high level of conflict in the South African workplace is due to the failure of organisations to incorporate black African values into corporate cultures. Mbigi (1995) believes that the concept of ubuntu is fundamental to the transformation of management in South Africa to develop productive, competitive enterprises. Mthembu (1996) argues that many problems faced by businesses in South Africa are due to the fact that they fail to take cognisance of African' values in their corporate cultures.

'[T]hey tend not to mobilise their full strength and potential because they are not connected to the majority of the workforce. In addition, many businesses fail to build on the full potential of the workforce, thereby preventing the development of a more authentic corporate culture' (Mthembu, 1996: 215).

This, these writers argue, is, in part, due to the fact the black African values have not been integrated into the workplace. 'Existing corporate cultures are foreign to most African workers' (Mthembu, 1996: 216).

Koopman (1994) notes that South African business cannot be successful until a set of common values exist and all parties create a common vision. He argues that white people and black people differ fundamentally in their basic values.

'Whites primarily have designed exclusive institutions which give primacy to the individual, his development, self fulfillment, which serve to foster liberal democracy. Blacks, on the other hand, believe that man is very much part of the societal fabric and see the need for each individual to find his place in a societal structure, to play his particular role in it and, to a large extent, subordinate himself to the societal needs. In other words, he desires organisations to be inclusive' (Koopman, 1994: 41).

Koopman (1994) and other writers noted above imply that creating a strong corporate culture with common values is possibly one such way of promoting inclusivity, and that until value differences have been resolved, one cannot expect to create successful organisations with common goals to which all employees aspire.

'We have to come to terms with each others' differences, acknowledge them and then, through the discovery of our own limitations, realise common values for a new economic dispensation' (Koopman, 1994: 43).

Values, according to Trompenaars (1993) and Hofstede (1997), are intrinsic to differences in cultures and determine the way in which people from different cultures will react to situations. Trompenaars notes that

'[i]f business people want to gain an understanding of and allegiance to their corporate goals, policies, products or services wherever they are doing business, they must understand what those and other aspects of management mean in different cultures (1993: 3).

In South Africa, the history of the diverse ethnic cultures that exist in the country may cast doubt on the existence of a single national culture or national value system. Rather. when national values are discussed in relation to Trompenaars (1993) and Hofstede (1997), a multitude of ethnic values could, it is suggested. exist in South Africa as hypothesised by Thomas \& Bendixen (1997). It would be expected, if one extrapolates from Hofstede's (1997) thesis that employees would bring such ethnic values to bear in the workplace.

Schein (1992) proposes that organisational culture can be understood by identifying the visible artifacts. espoused values and, at a deeper level, the underlying assumptions prevalent in an organisation or those solutions to problems that have worked over time and that have become taken for granted. It is only once the espoused values become basic underlying assumptions that they are translated into behaviour. Therefore, as Christie (1996) argues. it is futile for an organisation to generate a set of values that are displayed in prominent places while management waits for dramatic improvements in productivity and profitability. The values need to become part of the basic assumptions of the organisation before they can bring real change and cohesion to the culture of the organisation.

Peters \& Waterman (1984) and Lagan (1998) also argue for the creation of a common set of values and note that values must become the driving philosophy behind behaviour and decision making within the organisation. In this way, the espoused values are repeatedly applied to problems and when they are seen to be working. become, to apply Schein's (1992) theory, basic assumptions and part of the behaviour in organisations. Kotter \& Heskett (1992) and Blanchard \& O'Connor (1997) note the powerful role that values can play in developing high performance corporate cultures

Thomas \& Schonken (1998a: 1998b) note the hitherto lack of empirical evidence to support the propositions of writers who espouse the incorpration of black African values into business. However, the study of a South African company that actively promotes the establishment of a negotiated values base amongst employees is of interest. Such a study could cast some light on the debate as to whether the issue really is the incorporation of black African (ethnic) values into business or whether, indeed, the salient point is the creation of shared values by all that promote the working together of diverse employees in the achievement of corporate objectives

\section{Values-negotiation process at Group Africa}

One such South African management process and practice to address the development of a unified, yet diverse workforce. is the negotiated values system operative at Group Africa of the Amavulandlela. a marketing and communications company. An example of the diversity at Group Africa is that blacks (A frican, Coloured and Indian) constitute $72 \%$ of employees at management levels and $33 \%$ of employees at Director level. 2 The company specialises in face-to-face communication with developing markets in the country, in the rest of Africa and, more recently, internationally. The company is described by Boon (1997: 136) as 'a happy, productive exciting, interesting and profitable African ${ }^{3}$ business, which 
has discarded the rule books and, in so doing, has discovered a truly powerful African way'. It is proposed that the negotiated values process practiced by Group Africa could present some important ideas and principles for consideration by management in South Africa if it is effective in promoting the working together of diverse employees for competitive advantage.

The workforce of Group Africa comprises approximately 230 full-time employees in South Africa that has developed into 'a wonderful team with a "family" structure that shares a very special culture' (Boon, 1997: 136). Fundamental to this culture and 'family' environment is the negotiated values system that governs the way the company is run and the way in which its employees are managed.

'Group Africa believes that the workplace should reflect personal values and be in harmony with belief systems. The workplace should be a vehicle through and in which everyone is able to achieve their (sic) personal aspirations' (Boon, 1997: 136).

Assuming the values are congruent with the vision and mission of the organisation, then the achievement of personal goals, Boon (1997) believes, will lead to the achievement of the goals of the company.

Group Africa does not adopt a top-down approach to values creation. Values

'form part of individual belief systems and are therefore integral to every decision and step that a person makes. They are what we represent as human beings. To be accepted by the community, values have to be shared and created by that community' (Boon, 1997: 85).

Accordingly, all employees are involved in the negotiation of a values system for the company.

A broad definition of values is used in the Group Africa values creation process. Values are taken to mean the rules by which people govern their lives and include values, principles and behaviours. The values are identified at group forums and are discussed, negotiated and defined by the employees until a set of agreed values is identified. This process brings together the different values of the diverse workforce at Group Africa to create a common set of values that all are committed to upholding. This process has generated a list of 35 values to which employees at Group Africa subscribe.

The values system is maintained by a group of elders or individuals who are elected by the employees to ensure that all members of the Group Africa community uphold the values. Elders have two major roles. The primary role is to offer guidance (mentor the organisation and the individuals within it and to carefully guide the individuals in terms of how they should behave). The secondary role is to ensure that employees act in accordance with the values and to effect discipline if necessary.

The values list is constantly evaluated, questioned and redefined as the company faces new challenges, or as new employees join the company. The key driver of this constant evaluation of the values is the new employee. Within a few weeks of joining Group Africa, the new recruits ( $\mathrm{maK}$ wetha) are gathered together in an umhlangano (group discussion forum) with other employees of Group Africa. Here they dis- cuss the principles that are important to them and. in the process, the existing values list is reevaluated.

This initial values negotiation experienced by amaKuctho sends an important message to new recruits. From the start they learn that they have the power to change the company and that they are expected to speak their minds and express their opinions in an open forum. no matter who is present or what is being discussed.

Boon ${ }^{4}$ argues that the values system

'is absolutely intrinsic to the way we exist. These values are things that we, as human beings, have decided are personally important to us. We are then encouraged to explore what those behaviours, those words. mean and thereafter we are called on to be accountable to them at every stage or step of our business. from recruitment to how we interact with our clients. Every single aspect of our business is lead by those values and behaviours' (Pers. comm.. 1998).

Values play an important role in recruitment. appraisal and promotion, employee development. discipline and decision making at the company.

Boon (1997) also believes that the values system is a valuable tool to facilitate cultural understanding between employees. This understanding is developed during values discussions in umhlanganos. Employees are encouraged to express their points of view, and in this way. others are exposed to alternative attitudes and definitions of what is perceived to be right or wrong. The values system is therefore also a mechanism to create 'a really powerful team spirit'.

\section{Aims of the study}

The overall aim of the study was to evaluate whether the negotiated values system at Group Africa impacts on employee behaviour, as manifested in decision making. behaviour towards fellow employees and customers, and cultural interaction and understanding. A further aim was to explore whether the existing values at Group Africa could be grouped into succinct values categories.

The following two propositions were posited:

\section{Proposition 1: the negotiated values system guides em- ployee behaviour}

Schein argues that the espoused values of an organisation 'predict well enough what people will say in a variety of situations, but ... may be out of line with what they will actually do in situations where those values should be operating' (1992: 21).

It is only when the espoused values become basic underlying assumptions that they directly influence behaviour. Proposition 1 aimed to establish whether the espoused values of Group Africa have. in fact. become basic assumptions of the company that now are manifested in employee behaviour towards each other and in customer service.

Proposition I was divided into a number of sub-propositions, each investigating behaviour in different areas:

- The negotiated values system guides employee behaviour towards fellow employees:

- The negotiated values system guides employee behaviour towards customers; 
- The negotiated values system facilitates understanding and interaction between different cultural groups;

- The negotiated values system guides decision making.

Proposition 2: the negotiated values can be clustered into four values categories

Peters \& Waterman (1984: 285) note that the values lists of successful organisations are 'narrow in scope, including just a few values'. The current values list at Group Africa comprises 35 values, all of which, it can be argued, employees are expected to understand. If the negotiated values system is to be a useful tool for consideration by other companies, it may be more convenient if it complied with the Peters \& Waterman (1984) recommendation. Thus, the research relating to this proposition explored whether the current list could be simplified into categories of values.

\section{Methodology}

\section{Population}

Two populations were included in the research design - all 230 full-time employees of the company, and all customers serviced by Group Africa. The inclusion of customers in the study was based on the premise that, as a service organisation, customers are in direct contact with employees and that the true test of employee values being evidenced in behaviour is if such values are perceived by customers.

\section{Sample}

The entire population of full-time employees was surveyed. Part of the analysis of the data collected from employees involved the use of multivariate statistics. The minimum requirement for the use of these techniques is a sample size of between two and four times the number of data points. As there are 35 values in the Group Africa list, and these were the data that was to be subjected to multivariate analysis, a sample of at least 70 was required. Of the 230 full-time employees surveyed, 111 employees responded, thus satisfying the sample size requirement. The breakdown of the employee sample is shown in Table 1.

Convenience sampling was applied to the customer group. Leedy (1997: 204) defines convenience sampling as a nonprobability sampling method that 'takes units as they arrive on the scene or as they are presented to the researcher'. The disadvantage of this method is that the researcher has little control over whether the sample is, in fact, representative of the population. Senior managers at Group Africa supplied a list of customers who could be contacted to complete the customer questionnaire. Each customer was contacted telephonically, then faxed a questionnaire for completion. As the data received from this sample was not subjected to multivariate statistics, the 22 returned questionnaires were deemed sufficient for the purposes of this study.

\section{Questionnaire design and data analysis}

The employee questionnaire first comprised a series of questions to gather the demographic details of the respondents regarding age, sex, level of education, ethnic culture, length of service, geographic location and occupational level.

Two questions in the employee questionnaire required that respondents list the three major positive and negative features
Table 1 Demographic profile of employee sample

\begin{tabular}{|c|c|c|c|}
\hline Dimension & Description & $\begin{array}{l}\text { Number of } \\
\text { respondents }\end{array}$ & $\begin{array}{l}\text { Percentage } \\
\text { of simple }\end{array}$ \\
\hline \multirow[t]{2}{*}{ Gender } & Malc & 67 & $(x) \%$ \\
\hline & Remalc & 44 & $40 \%$ \\
\hline \multirow[t]{4}{*}{ Age } & $20-29$ & 35 & $32 \%$ \\
\hline & $30-39$ & 36 & $32 \%$ \\
\hline & $40-49$ & 31 & $28 \%$ \\
\hline & 50 plus & 9 & $8 \%$ \\
\hline \multirow[t]{8}{*}{ Cultural group } & Coloured & 2 & $2 \%$ \\
\hline & Indian & 1 & $1 \%$ \\
\hline & Sotho & 12 & $11 \%$ \\
\hline & White Afrikatams & 3 & $3 \%$ \\
\hline & White Inglish & 30 & $27 \%$ \\
\hline & Xhosa & 23 & $21 \%$ \\
\hline & Zulu & 29 & $26 \%$ \\
\hline & Other & 11 & $10 \%$ \\
\hline \multirow[t]{3}{*}{ Length of service } & Less than 2 years & 23 & $21 \%$ \\
\hline & $2-5$ years & 44 & $40 \%$ \\
\hline & Over 5 years & 44 & $40 \%$ \\
\hline \multirow[t]{6}{*}{ Geographic location } & Gauteng & 47 & $42 \%$ \\
\hline & Kwazulu Natal & 29 & $26 \%$ \\
\hline & Western Cape & 13 & $12 \%$ \\
\hline & Eastern Cape & 12 & $11 \%$ \\
\hline & Tzaneen & 9 & $8 \%$ \\
\hline & Other & 1 & $1 \%$ \\
\hline \multirow[t]{2}{*}{ Level in organisation } & Director & 4 & $4 \%$ \\
\hline & Manager & 21 & $19 \%$ \\
\hline$?$ & Employee & 86 & $77 \%$ \\
\hline \multirow[t]{6}{*}{ Highest level of education } & Primary school & 5 & $5 \%$ \\
\hline & High school & 32 & $29 \%$ \\
\hline & Matric & 30 & $27 \%$ \\
\hline & University & 19 & $17 \%$ \\
\hline & Technicon & 11 & $10 \%$ \\
\hline & Other & 14 & $13 \%$ \\
\hline Total & & 111 & \\
\hline
\end{tabular}

of the values system. Content analysis was used to group the responses received from these questions.

A further question contained a list of statements about the values system generated from Boon's (1997) book, interviews and discussions with employees. and observations of activities at Group Africa. Employees were asked to indicate the extent of their agreement with each statement. The objective was to determine how employees viewed the system and if it did appear to influence behaviour. The responses were grouped into two frequency tables. one for the positive features and one for the negative. A top two box and bottom two box score was also calculated to determine the total agreement or disagreement with each statement.

The opening questions of the customer questionnaire focused upon the reasons of respondents for using the services of Group Africa, and why they thought the company was unique. The objective was to establish whether or not 
customers spontaneously referred to the values system, or to any of the specific values of Group Africa. The data was analysed using content analysis.

The final question contained in both the employee and customer questionnaires listed the 35 values of Group Africa and asked respondents to rate the behaviour of Group Africa employees on a five-point scale with regard to these values. The data was analysed in a number of ways. First the data from the employee questionnaire was analysed in conjunction with the demographic data to ascertain whether there were any significant differences in the ratings across demographic groups. The Kruskal-Wallis test was used for this purpose as the data was ordinal in nature and there were more than two sets of data to be compared. The rating data from both questionnaires was ranked according to the mean score for each value, and then the two ranked data sets were compared. A Mann-Whitney $U$ Test was then conducted on the two sets of data to determine if there were significant differences in the ratings across the two samples.

The final analysis on the data from this question was a principle components analysis (PCA) which was run on the employee data only. This was undertaken to determine whether the list of 35 values could be condensed into categories of values that could make application easier elsewhere. As data was ordinal in nature, it had to be converted to interval data in order to apply the PCA. This was undertaken by using correspondence analysis as recommended by Bendixen \& Sandler (1995). The rescaled data values were then substituted for the old ones in the database and the PCA was run. The initial run indicated that a four-factor solution was preferable. The second run was analysed to determine which values loaded onto each factor, using a cutoff value of 0.5 as recommended by Sharma (1996). Cronbach's Coefficient Alpha was also calculated to test the reliability of each of the factors to ensure that none of the values should be excluded to improve the result. Details of the employee and customer questionnaires can be found in Doak (1998).

\section{Limitations}

- The present study did not measure the effect of the negotiated values system on employee satisfaction and productivity based on indicators relating to these two factors such as absenteeism, staff turnover et cetera (Meglino, Ravlin \& Adkins, 1989; Pulakos, Oppler, White \& Borman, 1989; Greenhaus et al, 1990; Tsui et al, 1992; Verkuyten, De Jong \& Masson, 1993; Bochner \& Hesketh. 1994; Leftkowitz, 1994; Smith, Smith. Olian, Sims, O'Bannon \& Scully, 1994; Mount. Hazucha, Holt \& Sytsma, 1995: Simons, 1995). Ideally, indicators such as those used in the above studies should be measured on a longitudinal basis.

- English was the language medium used in the questionnaires and. as such. could have involuntarily excluded employees (whose first language is not English) from the study or influenced their responses.

- While attempts were made to control for researcher bias, such contamination could have occurred in the questionnaire design and interpretation of results.

- Although a pilot study was conducted, the reliability and validity of the research instruments was not conclusively established.

- Senior members of (iroup Africa who provided the list of customers to be contacted determined the customer sam: ple. Such convenience sampling could have influenced the representative nature of the sample and led to the related possibility of sampling bias.

- The values stated in the Group Atrica values list have clearly defined meanings that have been defined by the employees during the values-negotiation process. These definitions were not provided to customers in the sample and accordingly, customer understanding of the words may differ to that of employees. thus requiring caution in the comparison of responses between employees and customers.

\section{Results}

Negotiated values system guides employee behaviour Proposition 1

The first sub-proposition addresses behaviour lowards tellow employees.

The responses displayed in Table 2 indicate that the values system impacts, to some extent. on employee behaviour.

Table 2 Positive features of the values system

\begin{tabular}{|c|c|c|}
\hline Feature & $\begin{array}{l}\text { Number of } \\
\text { revponses** }\end{array}$ & 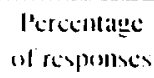 \\
\hline Influences hehaviour & 54 & $29.7 \%$ \\
\hline Brings people together lo build leimworh & 34 & 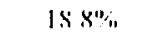 \\
\hline $\begin{array}{l}\text { Affects relationships within the work covirom- } \\
\text { ment }\end{array}$ & 27 & $1+5 \%$ \\
\hline Helps people to grow & 16 & $x \times \%$ \\
\hline Helps understand different cultures & 11 & $6 .(1) \%$ \\
\hline Improves performance & 9 & $+.0 \%$ \\
\hline Enhances the working con irumment & $x$ & $1+4 " \cdot 0$ \\
\hline Creates a shared vision & 7 & $; x^{4 !}$ \\
\hline Improves communicati(n) & 5 & $2.7 \%$ \\
\hline Improves contlict resolution & 4 & 2.20 \\
\hline Other & 7 & $i x \%$ \\
\hline Total & 182 & $1(1)$ \\
\hline
\end{tabular}

* Responses received. not number of repondents who answered the question

Table 3 Negative features of the values system

\begin{tabular}{|c|c|c|}
\hline Feature & $\begin{array}{l}\text { Vumber of } \\
\text { Reypumser }\end{array}$ & $\begin{array}{l}\text { Percentage wf } \\
\text { Respondes }\end{array}$ \\
\hline Is easily manipulatcd & $x+$ & $6,6^{\prime \prime} "$ \\
\hline The system is restrictive & 14 & $1+4 " \prime$ \\
\hline Too many grey arcias & 9 & $6.8^{\prime \prime}:$ \\
\hline Time consuming & 5 & $\therefore .8 \%$ \\
\hline Difficult to balance with business practices & 4 & $30 \%$ \\
\hline Too many valucs & 3 & $233^{\prime \prime \prime}$ \\
\hline Other & 8 & $6.1 \%$ \\
\hline Total & 1.32 & 1110 \\
\hline
\end{tabular}


From Table 3 the negative features of the values system, as identified by respondents, are noted.

An area of concern is the large percentage of negative responses regarding the manipulation of the system $(63.6 \%)$. A closer inspection of these responses indicated that they referred specifically to the value 'care'. This may be explained by the fact that the value 'care' is used in the performance umhlanganos (where the performance of an employee is evaluated by the group). In these umhlanganos, the value 'care' is stressed to the person being appraised. If this umhlangano is being used for counselling or disciplinary purposes, employees may be suspicious of this value.

From Table 4 it can be seen that employees respond favourably to other aspects of the values system.

Overall, there appears to be strong agreement with all the positive statements, as can be seen from the highlighted modal categories. and the top two box scores column for each statement. This is particularly evident in the areas of attitude towards the company. enthusiasm and commitment to the company. the promotion of cultural understanding, a sense of belonging. problem solving, personal development. and behaviour towards people from different backgrounds.
However, as can be seen from Table 4, there are noticeable exceptions, namely, the two statements regarding the elders: -The elders have really helped me when I have had a problem' and 'It is really nice to be able to take my problems to the elders instead of to my boss". For both of these statements the modal category is the column 'neither agree nor disagree'. This indicates ambivalence towards the use of the elders in problem solving or a lack of understanding as to the actual role of the elders in such cases. In contrast, the guidance of the elders and their mentoring role is clearly understood. as can be seen from the strong agreement $\left(79.3^{\circ} \%\right)$ with the statement 'I see the elders' role as one of guidance and mentoring'.

The analysis of the negative statements noted in Table 5 is supportive of findings noted in I able;

Three statements refer to the possible manipulation of the values system:

- 'People don't really follow or believe in the values":

- 'People don 't really take it seriously': and

- 'People just pay lip service to it'

As can be seen from Table 5. overall. respondents tend to disagree with these negative statements. with some exceptions. The first of these stitements. It is very time

Table 4 Values system descriptions: positive statements

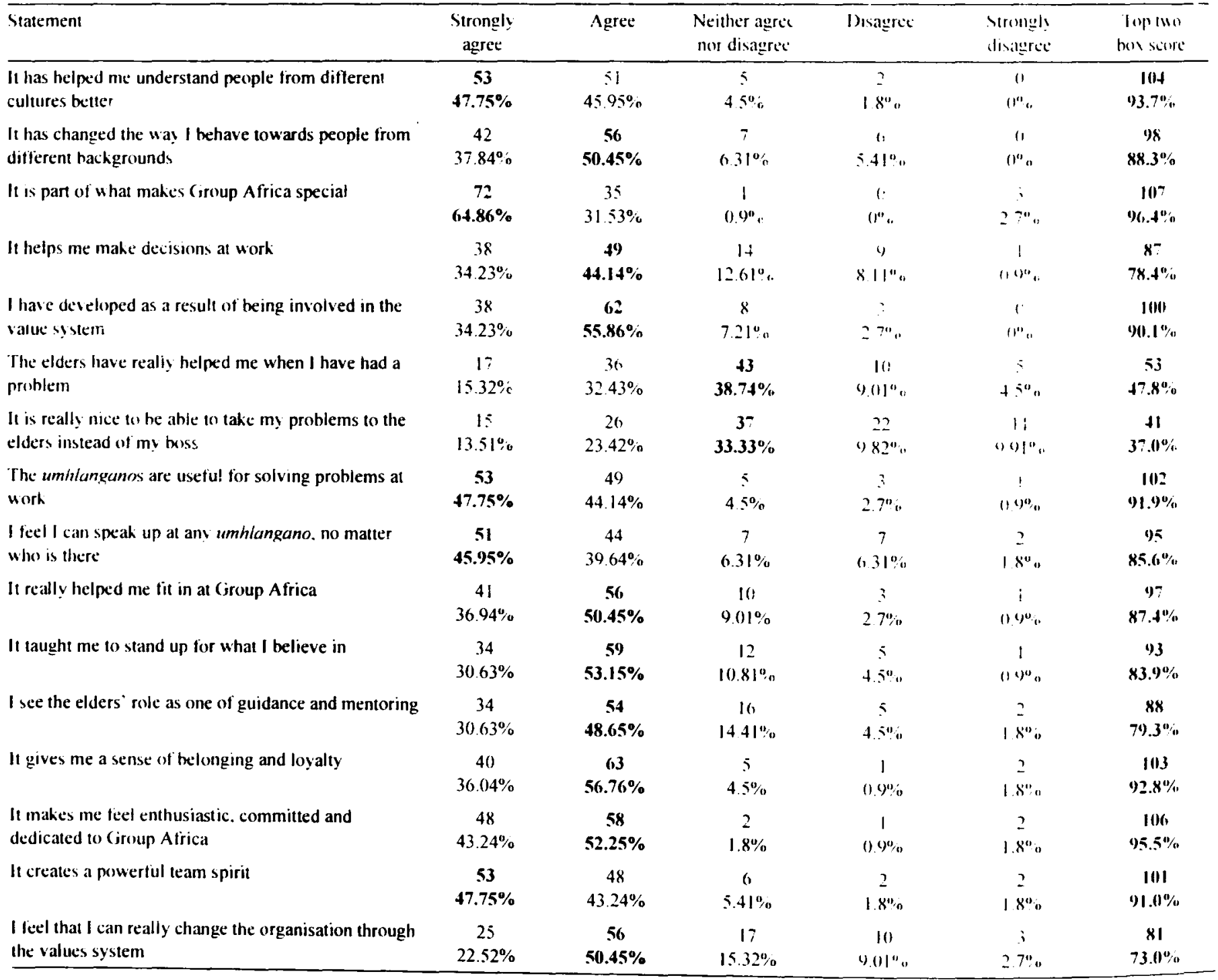


Table 5 Values system descriptions: negative statements

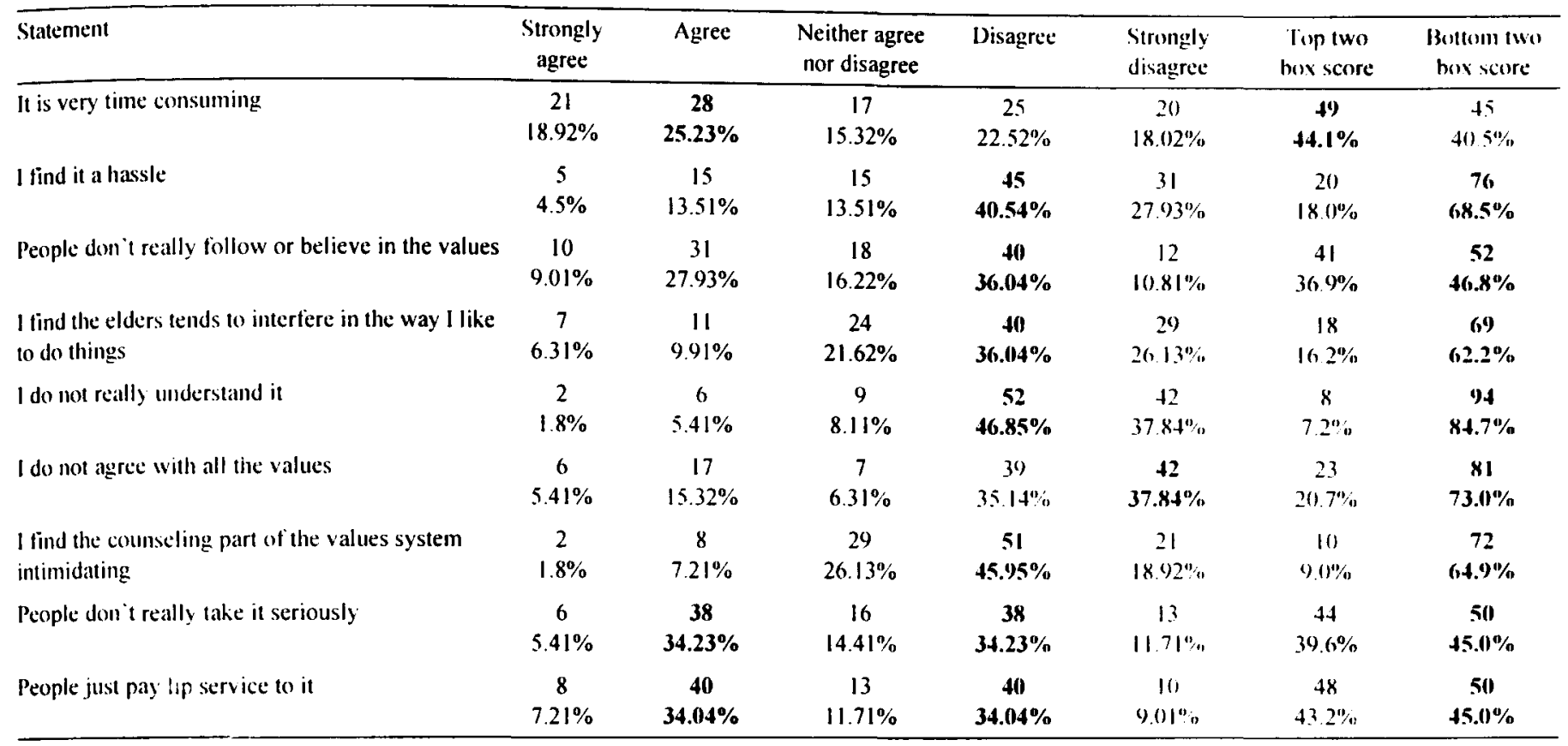

consuming is agreed to by $44.1 \%$ of respondents as opposed to the $40.5 \%$ who disagree. However, in contrast to this position, there is strong disagreement with the statement ' 1 find it a hassle'. Here. $68.5 \%$ of the respondents disagree with this sentiment. A possible explanation of this seeming contradiction is that employees may find the values-negotiation process time consuming, but they appear to be prepared to spend the time on it.

The last two statements in Table 5, 'People don't really take it seriously' and 'People just pay lip service to it'. are clearly bi-modal. indicating disagreement among employees as to how dedicated people are towards the values system. This is supportive of the findings noted in Table 3 . However, from the scores appearing in summarv columns in Table 5. (the top two and bottom two box scores), it can be noted that a slightly higher percentage of employees disagree with these two statements.

The overall results presented in Tables $4 \& 5$ indicate that emplovees are positive about the role of the values system in guiding behaviour at work and indicate that it is effective in this regarc.

Employees were required to rate the behaviour of their colleagues in terms of the values. A mean score out of five was calculated for each value and the values were then ranked. Overall. the scores for the values were high, ranging from 4.37 down to a lowest score of 3.75 (shown in Table 6). This indicates that the values, according to employees, are noticeable in the behaviour of their colleagues. Once again this is supportive of the proposition that the values guide behaviour towards fellow employees.

A final point to be made with regard to this sub-proposition is that all employees do not agree about the extent to which the values are translated into behaviour. There are significant differences in the ratings of most of the values across demographic categories, as the Kruskal-Wallis test results indicates (Table 7). The values where there are no significant differences across demographic groups are highlighted in bold.
These are: 'we are of Africa': 'personal': 'non-discriminatory": 'integrity': and 'acceptance of constructive criticism"

All of these values, with the exception of 'personal'. appear in either the top or bottom ten groups (Table 6). The fact that 'personal' does not appear only means that employees are in agreement that it lies elsewhere in the ranking and that all employees agree as to the rating of the value.

In conclusion. it is believed that the data supports the proposition that the negotiated values s! stem guides behaviour towards fellow emplovees. However, this is a qualified conclusion as there are areas where reservations are noted:

- There is a strong feeling that the system is manipulated by some employees:

- Some of the values are more noticeable in behaviour than others:

- The role of the elders in enforcing the values system is unclear to many employees: andi

- Employees from different demographic groups disagree on the extent to which the values are translated into behaviour.

The second sub-proposition investigates employee behavjour towards customers. Once again. it appears that the values system is effective in this regard.

Although there are no direct references to any of the values in the responses received from customers (shown in Tables 8 and 9), analysis of the relevant statements indicates that the following values are spontaneously alluded to by customers:

- We are of Africa":

- Natural drive to draw closer to other cultures": and

- 'Enthusiasm/passionate".

It is inferred. therefore, that customers notice these three values in the behaviour of Group Africa employees.

As with the results from the employer questionnaire. the mean score for each of the values was used to rank the values to highlight those that were more noticeable than others. (Oserall, the mean scores received from costomers were higher than those receised from employes. ranging from 4.98 to 4.65 as seen in figure 1. 
Table 6 Mean score for rating of values by employees

\begin{tabular}{|c|c|}
\hline Value & $\begin{array}{l}\text { Meatun em- } \\
\text { ployee rating }\end{array}$ \\
\hline We are of Africa & 4.37 \\
\hline We lead the way & 4.30 \\
\hline Pride in what we 6 & 4.26 \\
\hline Care & 4.26 \\
\hline Respect & 4.20 \\
\hline Team drisen & 4.19 \\
\hline We as a team are friends & +18 \\
\hline Participatise management/leadership & 4.17 \\
\hline Empathy & 4.10 \\
\hline Fun & 4.10 \\
\hline Enthusiasm/passionate & 4.99 \\
\hline Listen and hear & 4.09 \\
\hline Willingness to share & 4.08 \\
\hline Lonalty & 4.07 \\
\hline We do it & 4.06 \\
\hline Fairness & 4.00 \\
\hline Effective & 3.99 \\
\hline Honesty & 3.99 \\
\hline Manners & 3.99 \\
\hline Openness & 3.99 \\
\hline Trust & 3.98 \\
\hline Natural drive to draw closer to other cultures & 3.98 \\
\hline Willing to delegate to enable others to grow & 3.97 \\
\hline Pro-active & 3.97 \\
\hline Professionalism and dedication to task & 3.97 \\
\hline Understanding/good interaction & 3.96 \\
\hline Personal & 3.93 \\
\hline Faith in ourselves and each other's abilities & 3.93 \\
\hline Recognise achievement & 3.91 \\
\hline Dynamic & 3.90 \\
\hline Drive for personal development & 3.89 \\
\hline Acceptance of constructive criticism & 3.89 \\
\hline Able to offer constructive criticism & 3.86 \\
\hline Integrity & 3.85 \\
\hline Self disciplined & 3.80 \\
\hline Efticient & 3.76 \\
\hline Accept only the highest standards. according to group standards & 3.76 \\
\hline Non-discriminatory & 3.75 \\
\hline
\end{tabular}

It is possible that the reason for this finding is that customers are unaware of the values system and therefore do not judge Group Africa employees by the values. In contrast, employees are aware of the values and expect others to behave in accordance with them. Employees may therefore be more critical in their assessment.

When the top ten rankings from the employee and customer samples (Table 10) are compared, it can be seen that there are four values that rank in the top ten of both the customer and the employee samples (highlighted in bold).
Table 11 indicates the bottom ter values as ranked by enployees and customers.

Once again, there is agreement across bolh simples as to which values are least noticable in behar ione highliglated in bold). It is clear that these are the values thatl are the least noticeable in the behaviour of (iroup Africa cmplosecs.

If the top ten and bottom ten lists ( Iables in \& 11) are compared. it can be seen that there is clear disaderement on two of the values between the two samples the first of these is the value "we lead the was. This value ranks as number three on the employee list (Table (1)). but is the tenth worst ranked on the customer list (Tible 11 ). 11 k comployees believe that they do. in fact. lead the way. hut customers appear to feel differently about this. Howerer. it must be moted that the two samples may be evaluating this particular value differently. For example. employees may chaluate adherence to this value in terms of internal factors in the organisation such as the values system or the way they are treated. Customers, on the other hand. will most likels view this value in terms of the services provided by the compan! to them.

The second value where there is strone disagrement between the two samples is that of 'non-discrimination". This value ranks first on the customer list ( lable (0) but is ranked in the bottom ten list by cmployecs ( lable 11 ). Again, the difference could be explained by perceptions. It call be argued that Group Africa is one of the few or aanisations in South Africa that is representative of South $\Lambda$ fricin population demographics. From a customer perspective, this is probably very different to that which they encounter in their own organisations, hence the high score on this item. Imployees. on the other hand, may possibly assess this value from an internal perspective in terms of their behaviour towards onc another and therefore accord it a lower score.

The results of the Mann-Whitney (1-test ( Table 12) that was conducted on the employee and customer rankings indicate that there are nine values where there is no significant difference between the average ratings from the wo samples (highlighted in bold in the table). namely: respect": "willing 10 delegate to enable others to grow": "pro-active": "care": "self disciplined': 'participative management leadership'. 'recognise achievement": "we lead the way": and openness".

In conclusion. it appears that the data does support the subproposition that the values system guides employee behaviour towards customers. This is evident from the spontaneous references to certain of the values and from the high scores customers accord Group Africa employees in terms of the values. In fact. overall. the customer ratings are higher than are those obtained from emplosees and. in most cases. the difference is significint.

The third sub-proposition investigated whether the waltes system was effective in facilitating culturil understanding and interaction. Once again, the data is stpportive of this proposition.

The results from the content analysis of the employee questionnaire (Table 2) indicate a high proportion of responses relating to the unifying role of the values system in building teamwork (18.8\%). A high proportion of respondents also illdicated that the values system affects relationships within the working environment $\left(14.9^{\circ} \%\right)$ and $6^{\circ}$ o of respondents note that the values system assists in cultural understanding. () Ner 
Table 7 Kruskal-Wallis test results*

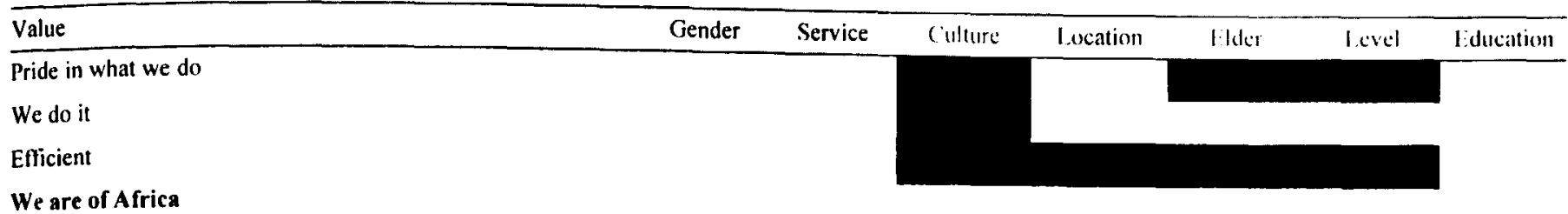

Personal

Effective

Faith in ourselves and each other's abilities

Loyalty

Respect

Willing to delegate to enable others to grow

Trust

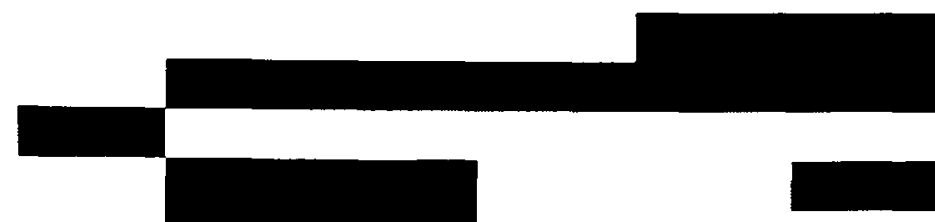

Natural drive to draw closer to other cultures

Dynamic

Honesty

Pro-active

Care

Understanding/good interaction

Enthusiasm/passionate

Accept only the highest standards, according to group standards

Non-discriminatory

Empathy

Self disciplined

Manners

We as a team are friends

Willingness to share

Team driven

Participative management/leadership

Fairness

Professionalism and dedication to task

Recognise achievement

Fun

We lead the way

Drive for personal development

Integrity

Openness

Able to offer constructive criticism

Listen and hear

Acceptance of constructive criticism

* Shading indicates a significant difference

Table 8 Reasons for choosing Group Africa

\begin{tabular}{lcc}
\hline Reason & $\begin{array}{c}\text { Number of } \\
\text { responses }\end{array}$ & $\begin{array}{c}\text { Percentage of } \\
\text { responses }\end{array}$ \\
\hline Understanding of the market & 9 & $29.0 \%$ \\
Good product & 6 & $19.4 \%$ \\
Good service & 6 & $19.4 \%$ \\
Relationship with clients & 3 & $9.7 \%$ \\
Quality of people & 2 & $6.5 \%$ \\
Other & 5 & $16.0 \%$ \\
\hline Total & 31 & $100.0 \%$ \\
\hline
\end{tabular}

Table 9 Reasons why Group Africa is unique

\begin{tabular}{lcc}
\hline Uniqueness & $\begin{array}{c}\text { Vimber of } \\
\text { responses }\end{array}$ & $\begin{array}{c}\text { Percentage of } \\
\text { responses }\end{array}$ \\
\hline Understanding of black culture & 16 & $47.1 \%$ \\
Group Africa s people & 8 & $23.5 \%$ \\
Tailored communication & 4 & $11.8 \%$ \\
Prioritise clients & 1 & $2.9 \%$ \\
Other & 5 & $14.7 \%$ \\
\hline Total & 34 & $100.0 \%$ \\
\hline
\end{tabular}


Fipure 1: Employee and Customer Riting of Values

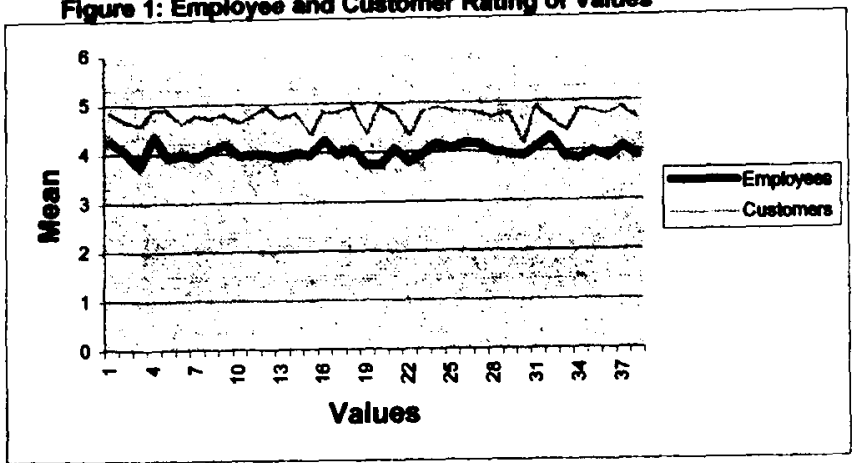

Figure 1 Employee and customer rating of values

all, of the 182 responses received to this question, 72 relate to the idea of bringing people together and facilitating understanding. The first two groupings mentioned above, namely building teamwork and positively influencing relationships inherently imply that the values process promotes the unification of employees from different cultural backgrounds.

From Table 4 it can be seen that a high level of agreement is indicated by respondents with regard to the two statements concerning the impact of the values system on cultural interaction:

- 'it has helped me understand people from different cultures' (93.7\%); and

- 'it has changed the way I behave towards people from different backgrounds' (88.3\%).
Given the results discussed above regarding the values system as a facilitator of cultural interaction and understanding. it is suggested that the findings indicate that the process of creating such values advance this goal. Thus, it is believed that this sub-proposition is supported by the data.

The fourth sub-proposition, namely that the values system guides decision making, is also supported by the data as is evident from Table 4 . Over $78 \%$ of the respondents agree with the statement 'it helps me make decisions at work'. While this percentage is somewhat lower than the percentage relating to agreement with some of the other statements, it nevertheless represents the opinion of the majority of respondents.

\section{Summary of results for Proposition 1}

Proposition 1 aimed to explore whether the values system influences employee behaviour. If the values are translated into behaviour, then, according to Schein (1992), they are no longer merely espoused values of the organisation, but have become basic assumptions that define how people will behave in any situation. It is believed, on the basis of the findings, that the data supports Proposition 1. The values system guides employee behaviour at the company, both within and towards customers. It also facilitates cultural understanding and interaction. It appears to be a possible tool for delegating authority and influencing employee activities without direct control by management.

Table 10 Top ten values

\begin{tabular}{lclc}
\hline Employee top ten & Mean & Customer top ten & Mcan \\
\hline We are of Africa & 4.37 & Non-discriminatory & 4.98 \\
Pride in what we do & 4.37 & Natural drive to draw closer to other cultures & 4.96 \\
We lead the way & 4.30 & Enthusiasm/passionate & 4.94 \\
Care & 4.26 & Fun & 4.93 \\
Respect & 4.20 & We as a team are friends & 4.9 .3 \\
Team driven & 4.19 & We are of Africa & 4.90 \\
We as a team are friends & 4.18 & Personal & 4.90 \\
Participative managementleadership & 4.17 & Listen and hear & 4.89 \\
Empathy & 4.10 & Pride in what we do & 4.87 \\
Fun & 4.10 & Willingness to share & 4.86 \\
\hline
\end{tabular}

Table 11 Bottom ten values

\begin{tabular}{lll}
\hline Employee bottom ten & Mean & Customer bottom ten \\
\hline Non-discriminatory & 3.75 & Recognise achievement \\
Accept only the highest standards according to group standards & 3.76 & Self disciplined \\
Efficient & 3.76 & Accept only the highest standards according to group standards \\
Self-disciplined & 3.39 \\
Integrity & 3.80 & Pro-active \\
Able to offer constructive criticism & 3.85 & Drive for personal development \\
Acceptance of constructive criticism & 3.86 & Efficient \\
Drive for personal development & 3.89 & Effective \\
Dynamic & 3.89 & Willing to delegate to enable other to grow \\
Recognise achievement & 3.90 & Acceptance of constructive criticism \\
\hline
\end{tabular}


Table 12 Mann-Whitney U-test results

\begin{tabular}{|c|c|c|c|}
\hline Value & $\begin{array}{c}\text { Mean employee } \\
\text { rating }\end{array}$ & $\begin{array}{c}\text { Mean customer } \\
\text { rating } \\
\end{array}$ & $\begin{array}{c}\text { Mann-Whitney } \\
\text { Test } \\
\end{array}$ \\
\hline Pride in what we do & 4.26 & 4.87 & $c>c$ \\
\hline We do it & 4.06 & 4.68 & $\mathrm{c}$ \\
\hline Efficient & 3.76 & 4.60 & $c>e$ \\
\hline We are of Africa & 4.37 & 4.90 & $c \times$ \\
\hline Personal & 3.93 & 4.90 & $c>c$ \\
\hline Effective & 3.99 & 4.63 & 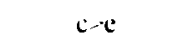 \\
\hline Faith in ourselves and each other's abilities & 3.93 & 4.78 & $c$ \\
\hline Loyalty & 4.07 & 4.71 & $c>c$ \\
\hline Respect & 4.20 & 4.82 & $r=\mathbf{c}$ \\
\hline Willing to delegate to enable others to grow & 3.97 & 4.63 & $r=c$ \\
\hline Trust & 3.98 & 4.77 & $\mathrm{c}>\mathrm{c}$ \\
\hline Natural drive to draw closer to other cultures & 3.98 & 4.96 & $c e$ \\
\hline Dynamic & 3.90 & 4.68 & $\mathrm{c}$ \\
\hline Honesty & 3.99 & 4.81 & $c>e$ \\
\hline Pro-active & 3.97 & 4.40 & $\mathbf{C}=\mathbf{e}$ \\
\hline Care & 4.26 & $\$ .81$ & $C=\mathbf{e}$ \\
\hline Understanding/good interaction & 3.96 & 4.82 & $\mathrm{c}>\mathrm{c}$ \\
\hline Enthusiasm/passionate & 4.09 & 4.94 & $\mathfrak{c c}$ \\
\hline Accept only the highest standards, according to group standards & 3.76 & 439 & $\mathrm{cec}$ \\
\hline Non-discriminatory & 3.75 & 4.98 & $c e$ \\
\hline Empathy & 4.10 & 4.80 & $c>c$ \\
\hline Self-disciplined & 3.80 & 4.36 & $C=e$ \\
\hline Manners & 3.99 & 4.82 & $c>e$ \\
\hline We as a team are friends & 4.18 & 4.93 & $\infty$ \\
\hline Willingness to share & 4.08 & 4.86 & $c>e$ \\
\hline Team driven & 4.19 & 4.83 & ce \\
\hline Participative management/leadership & 4.17 & 4.80 & $C=\mathbf{e}$ \\
\hline Fairness & 4.00 & 4.70 & $\mathrm{c}>\mathrm{c}$ \\
\hline Professionalism and dedication to task & 3.97 & 4.81 & $x^{\circ}$ \\
\hline Recognise achievement & 3.91 & 4.18 & $C=e$ \\
\hline Fun & 4.10 & 4.93 & cec \\
\hline We lead the way & 4.30 & 4.65 & $C=\mathbf{e}$ \\
\hline Drive for personal development & 3.89 & 4.42 & ce \\
\hline Integrity & 3.85 & 4.84 & $c \times$ \\
\hline Openness & 3.99 & 4.80 & $C=c$ \\
\hline Able to offer constructive criticism & 3.86 & 4.73 & ce \\
\hline Listen and hear & 4.09 & 4.89 & $c \times e$ \\
\hline Acceptance of constructive criticism & 3.89 & 4.65 & $\mathrm{cr}$ \\
\hline
\end{tabular}

Negotiated values can be clustered into four values categories - Proposition 2

The data that supports this proposition was derived from the PCA analysis applied to the results from the employee questionnaire where respondents were asked to rate the behaviour of their fellow employees against the values (refer Table 6). It was found that the values can be grouped into four distinct sets of values, each influencing behaviour in a different area of the work environment.

Table 13 highlights the four groupings identified by the
PCA and the list of values included in each. The first group of statements describes how employees perform their jobs. This factor is therefore labelled 'behavioural values'. Employees take pride in what they do, they are self-disciplined and personal, they get on with the job and take a personal interest in it, they are loyal, lead the way and are accepting of constructive criticism.

Factor 2 is termed 'interpersonal values' as the values here relate to how employees treat other people. They show respect, are honest in their dealings. are enthusiastic and 
Table 13 Factor Groupings

\begin{tabular}{lcc}
\hline Factor I Behav ioural values & Loading & Coefficient Alpha \\
\hline Pride in what we do & 0.6985 & 0.8125 \\
We do it & 0.6685 & 0.8128 \\
We are of Africa & 0.5772 & 0.8209 \\
Personal & 0.5843 & 0.8294 \\
Loyalty & 0.5807 & 0.8186 \\
Self disciplined & 0.5842 & 0.8056 \\
Acceptance of constructive criticism & 0.5402 & 0.8139 \\
We lead the way & 0.4388 & 0.8212 \\
Listen and hear & 0.4019 & 0.8151 \\
Cronbach's Alpha & & 0.8338 \\
\hline Factor 2 Interpersonal values & Loading & Coefficient Alpha \\
\hline Respect & 0.6799 & 0.8418 \\
Honesty & 0.6357 & 0.8582 \\
Pro-active & 0.6996 & 0.8468 \\
Care & 0.6588 & 0.8483 \\
Understanding/gond interaction & 0.6871 & 0.8445 \\
Enthusiasm. passionate & 0.7291 & 0.8468 \\
Trust & 0.5452 & 0.8443 \\
Natural drive to draw closer to other & 0.4995 & 0.8605 \\
cultures & & \\
Accept only the highest standards & 0.4346 & 0.8588 \\
according to group standards & & \\
Cronbach's Alpha & & 0.8645 \\
\hline Fact & Los & \\
\hline
\end{tabular}

\begin{tabular}{lcc}
\hline Factor 3 Developmental values & Loading & Coefficient Alpha \\
\hline $\begin{array}{l}\text { Faith in ourselves and each other's } \\
\text { abilities }\end{array}$ & 0.6088 & 0.8477 \\
Willing to delegate to enable others to & 0.7285 & 0.8238 \\
grow & & \\
Non-discriminatory & 0.6129 & 0.8511 \\
Empathy & 0.7106 & 0.8490 \\
Trust & 0.5259 & 0.8265 \\
Recognise achievement & 0.5856 & 0.8297 \\
Drive for personal development & 0.5122 & 0.8392 \\
Able to offer constructive criticism & 0.5624 & 0.8344 \\
Cronbach's Alpha & & 0.8552 \\
\hline Factor 4 Team building values & Loading & Coefficient Alpha \\
\hline Participative management/leadership & 0.7341 & 0.8885 \\
Fun & 0.6525 & 0.8849 \\
Integrity & 0.6441 & 0.8838 \\
Manners & 0.5070 & 0.8806 \\
Team driven & 0.5677 & 0.8927 \\
Recognise achievement & 0.5206 & 0.8847 \\
Drive for personal development & 0.5744 & 0.8796 \\
Openness & 0.5238 & 0.8803 \\
We as a team are friends & 0.3792 & 0.8897 \\
Willingness to share & 0.4944 & 0.8828 \\
Team driven & 0.4778 & 0.8875 \\
Professionalism and dedicaticn to task & 0.4641 & 0.8856 \\
Cronbach's Alpha & & 0.8937 \\
\hline & & \\
& & \\
\hline
\end{tabular}

passionate. show understanding. trust and care. have a natural drive to draw closer to other cultures and accept only the highest standards according to group standards.

The statements loading onto Factor 3 relate to how employees develop other members of staff and the factor is therefore called 'developmental values'. Employees have faith in their own and the abilities of others. show empathy. have a drive for personal development, are able to offer constructive criticism, are non-discriminatory. trust others. recognise achievement and are willing to delegate.

Factor 4 relates to teamwork. The work is team driven. the team members are friends. there is a willingness to share. a sense of openness. management favours participation and achievement. both team and personal achievement is recognised, people are treated fairly. the work is fun and teams display a sense of professionalism and dedication to the task. This factor is therefore called 'team building values'.

\section{Discussion}

In summary. the findings suggest that the values system is a useful tool in managing and guiding employee behaviour. both internally and towards customers. It also appears to be useful in guiding decision making in the organisation and in facilitating cultural interaction within a common operational framework, although employee demographic and employeecustomer differences are evident as to the extent of such success.

The study also suggests that the values advocated by Group Africa can be grouped into four categories of values that guide aspects of behaviour. Such a grouping of values could be useful if the process was to be considered by other organisations.

One of the strengths of the values system may lie in the nature of participation and interaction in the process in which everyone is involved and where the values are agreed to by all. Such practice appears to create the inclusive and collaborative managerial practices that Boon (1997) notes. Such a process is supported by Kotter \& Heskett (1992) and Blanchard \& O`Connor (1997) who argue that management needs to move from exclusive to inclusive practices.

\section{Implications for management}

As South African work places become more representative of the population. managers are faced with increasingly diverse workforces that need to be motivated. Establishing a common set of work-related values that all employees have a part in creating. has been proposed as one way of uniting diverse employees in their work towards corporate objectives (Lagan. 1998: Thomas \& Robertshaw, 1999).

Thomas \& Bendixen (1997) note how. in a study of diverse South African middle managers, general work-related values appear to be similar. The negotiated values system. as researched in the present work. calls into question whether the incorporation of African values as proposed by Mbigi ( 1995) and Mthembu (1996) is really the issue. Rather. it may be both the process and the outcome of establishing shared values by all employees who comprise the diverse tapestry of the South African workplace that should command attention. However, such a process is time consuming and requires a high level of commitment. trust. honesty and openness among 
all employees and between management and employees. It must also pervade all aspects of organisational life.

Kotter \& Heskett (1992), Schein (1992) and Blanchard \& O'Connor (1997) argue that leaders create the culture of an organisation. It is suggested that by incorporating an interactive leadership style (Boon, 1997), a process of creating shared values at work to unite diverse employees can be established. The major task of leaders, it is further suggested, is to drive this process, as has been the case at Group Africa (Nothling, 1998; Callanan, 1998; Buchanan, 1999). Perhaps the challenge to South A frican management is to evidence courageous leadership that, in action and not simply in words in annual reports, begins to truly believe that the greatest resource of an organisation is really its people.

\section{Notes}

1. The term 'African' as used by Mbigi (1995) and Mtembu (1996) refers to black African only.

2. Group Africa, Employment Equity Plan, 2000-2002.

3. Boon (1997) uses the term 'African' to denote all the peoples of South Africa who comprise the South African workforce.

4. Personal communication with Mike Boon, Executive Chairman of Group Africa, $5^{\text {th }}$ February, 1998.

5. Personal communication with Mike Boon, Executive Chairman of Group Africa. $5^{\text {th }}$ February, 1998.

\section{References}

Bantel, K.A. \& Jackson, S.E. 1989. Top management and innovations in management: does the composition of the top team make a difference? Strategic Management Journal, 10: 107-124

Bendixen, M. \& Sandler, M. 1995. Converting verbal scales to interval scales using correspondence analysis, Management Dynamics. $4(1): 32-50$.

Blanchard, K. \& O'Connor, M. 1997. Managing by values. San Francisco: Berrett-Koehler.

Bochner, S. \& Hesketh. B. 1994. Power distance, individualism/collectivism, and job-related attitudes in a culturally diverse work group. Journal of Cross-Cultural Psychology, 25: 233-257.

Boon. M. 1997. The African way: the power of interactive leadership. Second Edition. Johannesburg: Zebra Press.

Buchanan, F.S.M. 1999. Leadership qualities for managing employee diversity. Unpublished Master of Management Research Report. Johannesburg: University of the Witwatersrand.

Callanan, G.I. 1998. The management of diversity: implications of organisational structure, systems, style and shared values. Unpublished MBA Research Report, Johannesburg: University of the Witwatersrand.

Christie, P. 1996. Stories from an (Af)manager. Randburg: Knowledge Resources.

Cox. T.H 1993. Cultural diversity in organizations: theory, research and practice. San Francisco: Berrett-Koehler.

Cox. T.H., Lobel, S.A. \& McLeod, P.L. 1991. Effects of ethnic group cultural differences on cooperative and competitive behavior on a group task. Academy of Management Journal, 34: 827-847.

Doak, R. 1998. The impact of values on employee behaviour and on customer perception of service. Unpublished MBA Research Report. Johannesburg: University of the Witwatersrand.

Glick, W.H.. Miller, C.C. \& Huber, G.P. 1993. The impact of upper echelon diversity on organizational performance. In Huber. G.P. \& Glick, W.H. eds. Organizational change and redesign: ideas and insights for improving performance. New York: Oxford University Press: 176-124.
Greenhaus, J.H.. Parasuraman. S. \& Wormley. W.M. 1990. Effects of race on organizational experiences. job performance evaluations. and career outcomes, dcademv of Management Journal. 33 : 6486.

Hofstede, G. 1997. Cultures and organizations: software of the mind. New York: Mc(jraw-Hill.

Institute for Management Development. 1999. World competitiveness: On Line, http://www ind ch/wcy/factors/overall.html.

Koopman. A. 1994. Transcultural management: in search of pragmatic humanism. In Christie. P.. L.essem. R. \& Mbigi. L. eds. African management: philosophies, concepts and applications it ed. Randburg: Knowledge Resources: 41-76.

Kotter, J.P. \& Heskett. J.L. 1992 ('orporate culture and performance. New York: The Free Press

Lagan. A. 1998. Recognising the value in values. IIR Monthly. August: $28-29$.

Lattimer, R.L. 1994. Team performance and diversity: process and productivity. Atlanta: Towers Perrin.

Leedy, P. 1997. Practical research: planning and design. $6^{\text {th }} \mathrm{ed}$. Ohio: Prentice Hall.

Lefkowitz. J. 1994. Race as a factor in joh placement: serendipitous findings of 'ethnic drift'. Personmel Psychology. 47: 497-513.

Mbigi. L. 1995. Ubuntu: the spirit of African transformation management. $1^{\text {st }} \mathrm{ed}$. Randburg: Knowledge Resources.

McLeod. P.L. \& Lobel. S.A. 1992. The effects of ethnic diversity on idea generation in sinall groups. Academy of Management best Paper Proceedings: 227-231.

Meglino, B.M. Ravlin, E.C \& Adkins, (.L. 1989. A work values approach to corporate culture: a field test of the value congruence process and its relationship to individual outcomes. Journal of $A p$ plied Psychology, 74: 424-432.

Morrison, A.M. 1989. The new leaders: guidelines on leadership diversity in America. San Francisco: Jossey-Bass.

Mount, M.K.. Hazucha. I.F.. I lolt. K.E. \& Sytsma. M. 1995. Raterratee race effects in performance ratings of managers, Acodemy of Management Best Papers Procecedings: 141-145.

Mthembu, D. 1996. African values: discovering the indigenous roots of management'. In Lessem. R. \& Nussbaum. B. eds. Savubona Africa: embracing four worlds in South lfrican manageme'nt. I" $^{\text {th }}$ ed. Sandton: Zebra Press: 215-226.

Nothling. C. 1998. A case study examining South African leadership. Unpublished MBA Research Report. Johannesburg: University of the Witwatersrand.

Peters, T. \& Waterman. R. 1984. In search of excellence: lessons from America's best-run companies. I" $\mathrm{ed}$. New York: Warner Books.

Pulakos, E.D., Oppler. S.H. White. I.A \& Borman. W.C. 1989. Examination of race and sex effects on performance ratings. Jentrnal of Applied Psycholog: 74: 770-780.

Republic of South Africi. 1998. Employment Equity Act. No. 55. Government (iazette'. No. 19370). Preitoria: (jovernment Printer.

Schein. E.H. 1992. Organizational cuilure and leadership). 2mil ed. San Francisco: Jossey-13ass l'ublishers.

Sharma. S. 1996. Applied multivartute redmiques. I" ed. New Y'ork John Wiley and Sons.

Simons, T. 1995. Top management team consensus, helerogeneity. and debate as contingent predictors of company performance: the complementarity of group structure and process. Accalemy of Management Best Papers Procesedings: 62-66.

Smith. K.G.. Smith, K.A.. ()lian. I.D.. Sims. H.P.. ()'Bannon. I).P. \& Scully, J.A. 1994. Top management team demography and proceess: the role of social integration and communication. Adminstrotive Science Quarterly. 39: $412-438$. 
Thomas, A. 1996. Going beyond affirmative action: managing diversity in South African organisations. Rivonia: Business and Marketing Intelligence.

Thomas. A. \& Bendixen. M.. 1997. Ethnic culture in South Africa: an international perspective on competitiveness. Proceedings of the Sixth Symposium on Cross-Cultural Consumer and Business Studies. Hawaii, December 10-13: 38-43.

Thomas, A. \& Robertshaw, D. 1999. Achieving employment equity: a guide to effective strategies. Randburg: Knowledge Resources.

Thomas, A.\& Schonken, J.S. 1998a. Culture specific management and the African management movement - a critical review of the literature. South African Journal of Business Management. 29(2): 53-66.

Thomas. A. \& Schonken, J.S. 1998b. Culture specific management and the African management movement - verifying the premises, South African Journal of Business Management, 29(2): 67-75.

Thomas. D.A. \& Ely. R.J. 1996. Making differences matter: a new paradigm for managing diversity. Harvard Business Review. Seplember-October: 79-90.

Thomas. R.R. (Jr). 1991. Beyond race and gender: unleashing the power of your total workforce by mamaging diversity. New York: AMACOM.

Trompenaars, F. 1993. Riding the weives of culture: understanding cultural diversity in business. London: Nicholas Brealey Publishing Limited.

Tsui, A.S.. Egan. T.D. \& ( $)^{\circ}$ Reilly. A.('. 1992. Being different: relational demography and organizational attachment. Administrative Science Quarterly. 37: 549-579.

Verkuyten. M.. de Jong. W. \& Masson. ('N. 1993. Job satisfaction among ethnic minorities in the Netherlands. Ippliced Pswethology: An International Revilew. 42: 171-189

Watson. W.E. Kumar. K. \& Michaelson. I.K. 1993. Culturil diversity's impact on interaction process and pertormance: comparing homogeneous and diverse task groups". Iculemy of 1/amegement Journal. 36: 590-6(1)

Wiersema. M.F. \& Bantel. K.A. 1992. Top management team demography and corporate strategic change. fecolemy of Honagement Journal. 35: 91-121. 